\title{
ЖИТТЕВИЙ ЦИКЛ ПРОЕКТУ ТА ЙОГО УДОСКОНАЛЕННЯ ПІД ЧАС ВПРОВАДЖЕННЯ ПРОЕКТУ
}

\section{PROJECT LIFE CYCLE AND ITS IMPROVEMENT BY THE PROJECT}

\section{Представив д-р техн. наук, професор В.В. Фурсов}

Постановка проблеми. Проектна діяльність пронизує сьогодні всі сфери функціонування будь-яких підприємств: у маркетингу - це проекти маркетингових досліджень, рекламних акцій, виведення на ринок нових продуктів, завоювання нових ринків збуту; у дослідно-конструкторських підрозділах — це проекти розробки нових продуктів, технологій; у виробництві проекти освоєння випуску нової продукції, технічного переозброєння, впровадження нових технологій; у збуті - проекти побудови торговельно-збутової мережі... Із входженням підприємств у ринок актуальними стають комплексні проекти їх реструктуризації з низкою субпроектів зі зміни продуктового портфеля, організаційної та виробничої перебудови, впровадження фінансового менеджменту, контролінгу тощо.

Проектна діяльність має вплив на стан підприємства, у межах якого вона здійснюється. Працездатність цієї системи залежить від якості формування портфелю проектів та ефективності їх оцінки на передінвестиційній фазі. 
Мета дослідження. Розглянути існуючі підходи щодо життєвого циклу проекту та удосконалити його шляхом доповнення необхідними видами робіт передінвестиційної фази. Це дасть можливість своєчасного внесення змін в стратегію діяльності проектноорієнтованих підприємств.

Основна частина (результати експериментального дослідження). Фази життєвого циклу проекту подано на рис. 1 (складено на основі [1]).

Згідно $з$ даними «Словника-довідника 3 питань управління проектами» (за ред. С.Д.Бушуєва), «фаза проекту - це певний обмежений проміжок часу виконання проекту, раціонально виділений у відношенні до інших проміжків» [1]. У даній роботі розглядається характеристика типових фаз життєвого циклу проекту.

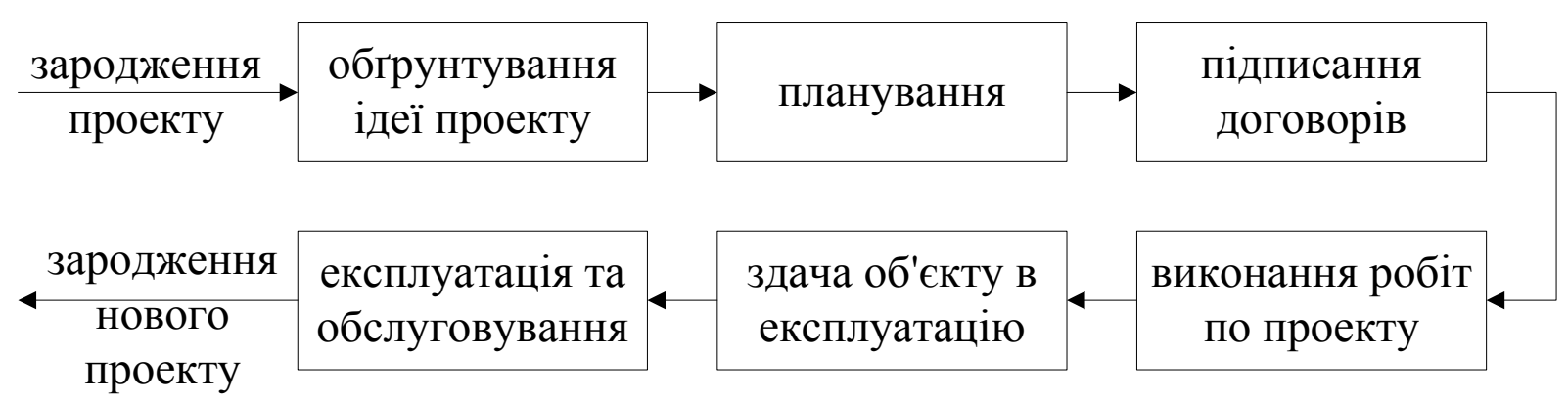

Рис. 1. Типові фази життєвого циклу проекту

Серед ряду визначень поняття «життєвий цикл проекту» доцільно навести найбільш поширені 3 них. Зокрема, у «Керівництві 3 основ проектного менеджменту» термін «життєвий цикл проекту» трактується таким чином: «множина послідовних фаз проекту, назви та кількість яких визначається залежно від потреб контролю організації або організацій, залучених до проекту» [2]. Перевагою даного визначення $є$ те, що його автор наголошує на тісному зв'язку сутнісних і кількісних характеристик фаз життєвого циклу 3 конкретними інтересами, потребами, пріоритетами тощо відповідних залучених організацій та зацікавлених осіб.

«Словник-довідник 3 питань управління проектами» (за ред. С.Д. Бушуєва) містить щонайменше два визначення терміну «життєвий цикл проекту». По-перше, життєвий цикл проекту (Project Life Cycle) визначається як «проміжок часу між моментом появи проекту й моментом його ліквідації» [1].
По-друге, дане поняття може мати дещо ширше визначення, а саме: «це послідовність фаз проекту, потрібних для досягнення визначеної мети, 3 моменту формування концепції проекту до його завершення, включаючи реалізацію й використання» [1]. Обидва вищенаведені визначення $\epsilon$ науково обгрунтованими. Якщо у першому з них наголос робиться на тривалості проекту та окремих його фаз, то зміст другого визначення зосереджено переважно на структурованості проекту, на його поділі на конкретні фази або етапи.

На основі наведеного вище можна сформулювати визначення поняття «життєвий цикл проекту», яке не суперечить жодному зі згаданих у даній статті визначень i включає основні положення кожного 3 них. Отже, життєвий цикл проекту - це сукупність кількісно та сутнісно залежних від специфіки проекту фаз від початку до завершення (ліквідації) проекту, поетапна реалізація яких забезпечує досягнення поставлених перед проектом завдань. 
Змістовно та стисло графічну інтерпретацію життєвого циклу проекту подали Грей К.Ф. та Ерік У. Ларсон [3], що показано на рис. 2.

Розглядаючи життєвий цикл проекту, автори графіка виділяють рівень зусиль як один 3 визначальних параметрів. 3 графіка видно, що рівень зусиль поступово зростає до i частково протягом реалізації фази виконання, після якої спостерігається його поступове зменшення. Зростання рівня зусиль обумовлюється поетапним збільшенням кількості роботи за проектом і підвищенням ступеня іiі складності протягом життєвого циклу. На фазі доставки обсяги робіт за проектом скорочуються, а відповідно, і рівень зусиль зменшується.

Окрім графічного виразу (рис. 2) життєвого циклу проекту, у статті подано стислий опис відображених фаз. На фазі „визначення” запропонована ідея конкретизується: окреслюються мета, задачі, основні принципи й положення проекту, висуваються найважливіші вимоги до складу та членів команди проекту, рівня їх відповідальності за прийняті зобов'язання в рамках проекту. Рішення, прийняті на фазі визначення, становлять основу, своєрідний фундамент проекту. До головної мети, принципів і положень проекту суттєві зміни, як правило, не вносяться.

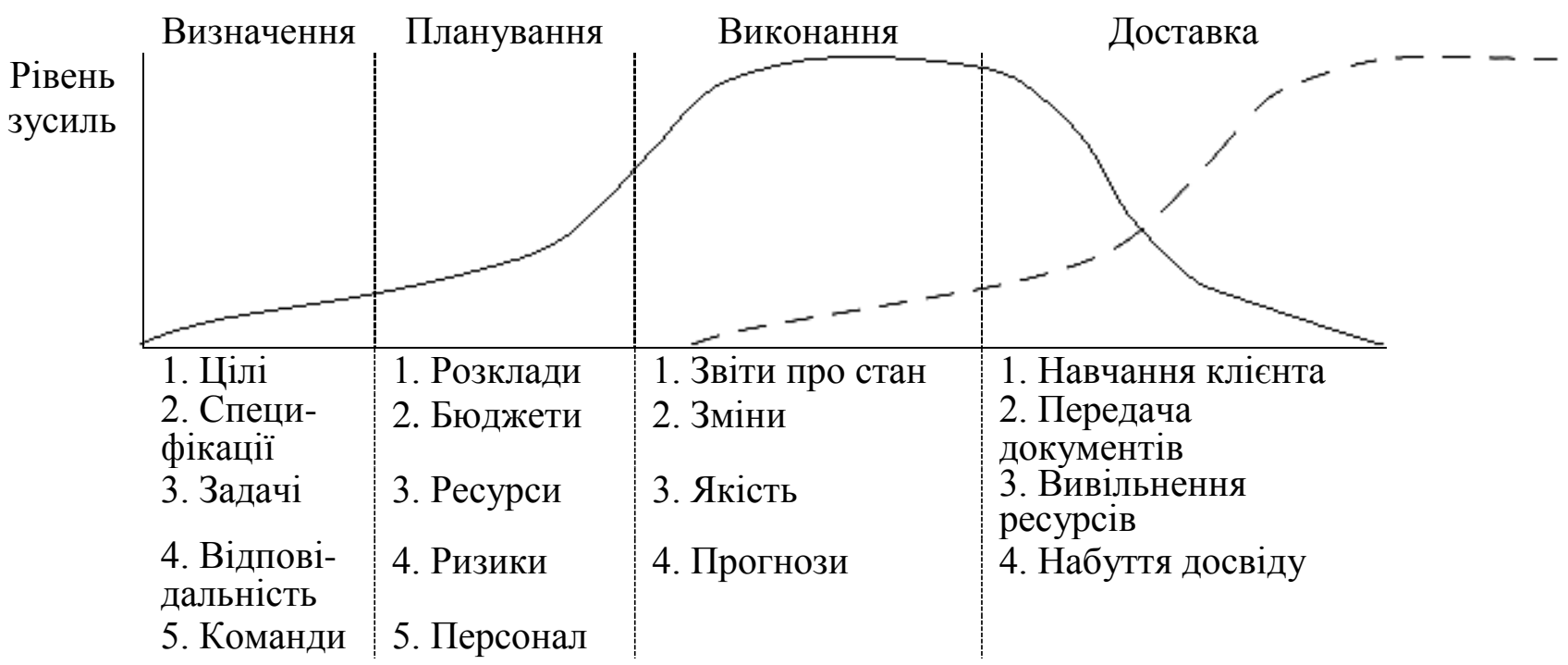

Рис. 2. Життєвий цикл проекту [3]

Плани, розклади, бюджети тощо, розроблені на фазі „планування”, по ходу реалізації проекту можуть змінюватися. На фазі „виконання” в них вносяться зміни, доповнення, поправки, які дозволяють робити проект більш гнучким, адаптованим й адекватним навколишньому середовищу, в якому реалізується даний проект.

Характерною особливістю фази „виконання” є безпосередня реалізація проекту на практиці, створення об'єкта проекту, а також контроль за процесом виконання та якістю робіт за проектом; формулюються звіти про хід виконання проекту та реалізацію за окремими елементами об'єкта проекту; розробляються прогнози стосовно подальшого функціонування об'єкта проекту.

На останній фазі життєвого циклу проекту „доставка” здійснюється навчання персоналу організації-клієнта у ефективній i безпечній роботі 3 проектом або створеним в результаті його реалізації об'єктом. Окрім того, формується, акумулюється та передається замовнику весь комплекс необхідної документації. На 
останній фазі життєвого циклу проекту аналізується сам проект, виконана в його рамках робота, сильні та слабкі сторони, переваги, успіхи, недоліки, невдачі, їх причини, формулюються рекомендації щодо їх запобігання або усунення їх негативних наслідків і т.П., що в загальній сукупності становить набутий досвід, який буде використовуватися командою проекту в майбутній роботі над подібними проектами [3].

Найбільш узагальнено фази життєвого циклу подав Дункан Вільям Р., обравши як визначальні два параметри: час і рівень вартості та кількість персоналу автор виділив такі фази життєвого циклу проекту [2]:

- початкова фаза - ініціація проекту, попередня обробка ідеї проекту, визначення місії проекту та найбільш принципових його властивостей i характеристик; формування концепції проекту, загального уявлення про проект;

- перехідні фази (одна чи кілька) грунтовна робота над основними складовими та деталями проекту, безпосередня реалізація проекту на практиці; характеризується досягненням на певному етапі найвищого рівня вартості та кількості залученого до впровадження проекту персоналу; кількість перехідних фаз життєвого циклу проекту прямо залежить від рівня масштабності, складності та тривалості самого проекту;

- заключна фаза - включає діяльність, здійснення якої забезпечує належне завершення, закриття проекту; дана фаза доходить кінця при ліквідації проекту, тобто або остаточного створення (зведення) об'єкта проекту, або демонтажу об'єкта проекту.

Наведений вище підхід до розподілу життєвого циклу проекту на фази $\epsilon$, по суті, досить спрощеним, проте властивим для всіх проектів, незалежно від їх сутнісних, часових, фінансових та інших характеристик.

Широковідомою $є$ точка зору, згідно 3 якою життєвий цикл проекту можна умовно поділити на чотири фази (рис. 3): передінвестиційна, інвестиційна, експлуатаційна, фаза закриття проекту.

Поєднавши проаналізовані підходи до життєвого циклу проекту (рис. 1,3 ) можна зробити висновок, що в одному 3 них подаються загальновизнані фази проектування, а в іншому розглядаються види робіт, які забезпечують ці фази. Все перераховане вище можна подати у вигляді таблиці.

\section{зародження \\ проекту}

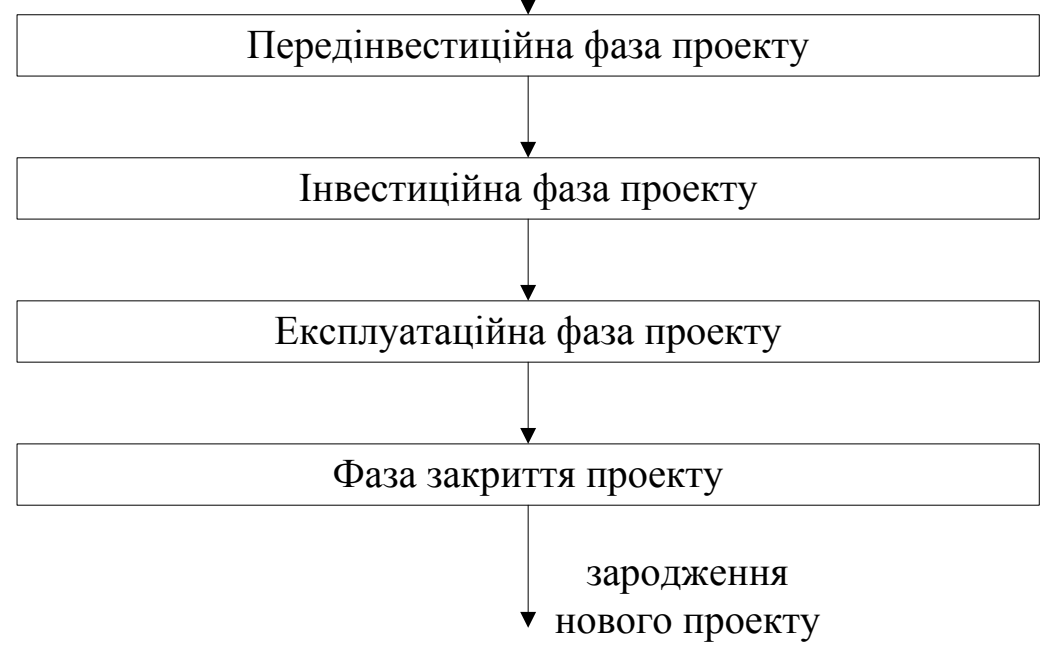

Рис. 3. Схема поділу життєвого циклу проекту на фази [4] 
Перелік видів робіт, що виконуються у межах фаз

\begin{tabular}{|c|c|}
\hline Фаза проекту & Види робіт у межах фази \\
\hline Передінвестиційна & $\begin{array}{l}\text { - формування портфелю проектів; } \\
\text { - обгрунтування ідеї проекту; } \\
\text { - планування; } \\
\text { - підписання договорів }\end{array}$ \\
\hline Інвестиційна & $\begin{array}{l}\text { - виконання робіт за проектом; } \\
\text { - здача об’єкта в експлуатацію }\end{array}$ \\
\hline Експлуатаційна & $\begin{array}{l}\text { - експлуатація; } \\
\text { - обслуговування }\end{array}$ \\
\hline Закриття & \\
\hline
\end{tabular}

В таблиці кожна фаза структурована за конкретними видами робіт. На думку автора даної роботи, на передінвестиційній фазі для обгрунтування актуальності впровадження проекту необхідно здійснювати оцінку працездатності системи. Вона створить умови для визначення стану процесі, що відбуваються до початку проектування та виявлення найбільш ризикованих галузей, які потребують своєчасних змін. Це дасть можливість формувати портфель проектів та вчасно визначати, який саме проект $\epsilon$ актуальним у теперішній час. А уже після обрання проекту застосувати ТЕО для підрахунку показників його ефективності. Тому, на думку автора, кожному проектноорієнтованому підприємству необхідно використовувати оцінку працездатності його стану за допомогою системи математичних методів.

Різні керівники проектів розглядають питання життєвого циклу по-різному, значною мірою на це впливають характер та особливості того чи іншого проекту, його зміст.

\begin{abstract}
Висновки 3 дослідження i перспектива, подальший розвиток у даному напрямку. Передінвестиційна фаза відіграє найважливішу роль у реалізації проекту, тому що закладає основи оптимізації кількісних i якісних параметрів, дозволяє домогтися розумного співвідношення між витратами й ризиками при прийнятті рішень із питань реалізації проекту. Ретельно проведені передінвестиційні дослідження найважливіша умова успішності проекту в цілому. Тому автором запропоновано ввести до іiі складу оцінку стану працездатності системи, що перебуває в умовах проектування. Це сприятиме правильному вибору галузі підприємства, яка потребує своєчасних змін та дозволить домогтись розумного співвідношення між витратами й ризиками при прийнятті рішень із питань реалізації проекту. Усе це дає змогу своєчасно оцінювати та при необхідності вносити зміни до стратегії подальшого розвитку системи. Це забезпечить працездатність ії діяльності.
\end{abstract}

\section{Сиисок літератури}

1. Бушуєв, С.Д. Словник-довідник 3 питань управління проектами [Текст] / С.Д. Бушуєв. - К.: Видавничий дім «Деловая Украина», 2001.- 640 с.

2. Дункан Вільям, Р. Керівництва з питань проектного менеджменту [Текст] / Вільям Р. Дункан, С.Д. Бушуєва. - К.: Інститут менеджменту і бізнесу, 2000.- 197 с. 
3. Грей, К.Ф. Управление проектами [Текст]: практич. пособие. / К.Ф. Грей, Э.У. Ларсон. - М.: Дело и Сервис, 2003.- 527 с.

4. Катасонов, В.Ю. Проектное финансирование [Текст]: Мировой опыт и перспективы для России / В.Ю. Катасонов, Д.С. Морозов, М.В. Петров. - М.: Анкил, 2001. - 312 с.

Ключові слова: проект, проектна діяльність, життєвий цикл проекту, фази, передінвестиційна фаза, надійність.

\section{Анотаціï}

Проведено аналіз існуючих підходів щодо життєвого циклу проекту та удосконалення його шляхом доповнення необхідними видами робіт передінвестиційної фази. Це дасть змогу для своєчасного внесення змін в стратегію діяльності системи під час впровадження проекту.

Проведен анализ существующих подходов к жизненному циклу проекта и усовершенствованию его путем дополнения необходимыми видами работ прединвестиционной фазы. Это даст возможность для своевременного внесения изменений в стратегию деятельности системы во время внедрения проекта.

Analysis of the existing approaches to the project life cycle and improved it by supplementing the necessary kinds of work the pre-investment phase. This will give the opportunity for timely внресения changes in the strategy for the activity of the system during project implementation. 